\title{
Ion Channels and Thermosensitivity: TRP, TREK, or Both?
}

\author{
J. Antonio Lamas *D, Lola Rueda-Ruzafa ${ }^{\dagger}$ and Salvador Herrera-Pérez ${ }^{\dagger}$ (D) \\ Laboratory of Neuroscience, Biomedical Research Center (CINBIO), University of Vigo, 36310 Vigo, Spain; \\ lolarrzg@gmail.com (L.R.-R.); ssalva4@me.com (S.H.-P.) \\ * Correspondence: antoniolamas@uvigo.es; Tel.: +34-986-812-563 \\ t These authors contributed equally to this work.
}

Received: 2 April 2019; Accepted: 7 May 2019; Published: 14 May 2019

\begin{abstract}
Controlling body temperature is a matter of life or death for most animals, and in mammals the complex thermoregulatory system is comprised of thermoreceptors, thermosensors, and effectors. The activity of thermoreceptors and thermoeffectors has been studied for many years, yet only recently have we begun to obtain a clear picture of the thermosensors and the molecular mechanisms involved in thermosensory reception. An important step in this direction was the discovery of the thermosensitive transient receptor potential (TRP) cationic channels, some of which are activated by increases in temperature and others by a drop in temperature, potentially converting the cells in which they are expressed into heat and cold receptors. More recently, the TWIK-related potassium (TREK) channels were seen to be strongly activated by increases in temperature. Hence, in this review we want to assess the hypothesis that both these groups of channels can collaborate, possibly along with other channels, to generate the wide range of thermal sensations that the nervous system is capable of handling.
\end{abstract}

Keywords: temperature; thermosensors; TREK channels; TRP channels

\section{Introduction}

Mammals and other animals spend large amounts of energy in maintaining a nearly constant body temperature, irrespective of the temperature of the environment. The mechanisms controlling thermal regulation are complex and often rely on negative feedback, where it is first necessary to determine the body and ambient temperature. The temperature of the environment can be sensed by external receptor cells, mainly located in the skin, whereas body temperature is sensed by internal receptors expressed by cells located in several internal organs. Traditionally, only the skin and core thermoreceptors (spinal cord, hypothalamus) have attracted the attention of researchers, but more recently, some very interesting information has emerged regarding visceral thermal receptors, even in humans [1,2]. Although a hypothesis conceived many years ago, the terminals of receptor neurons are thought to contain branches of nerve fibers without any apparent structural specialization. Indeed, only recently have we begun to understand the molecular basis of thermoreception by cells.

Many biochemical processes like chemical reactions, and physical processes like conformational changes, are extraordinarily dependent on temperature, and although these processes generally occur faster at higher temperatures, the relationships can be very complex [3]. If we consider the nervous system (NS), the effects of temperature on the resting membrane potential (RMP) were the first to be studied, as were its effects on the kinetics and speed of compound and single action potentials, long before the existence of ion channels was demonstrated [3-8].

All neurons and ion channels are affected by changes in temperature, not least because channel gating is generally a temperature-dependent process [9]. However, only some neurons can be called 
thermoreceptors and very few ion channel types can be designated as thermosensors. In general, only channels with a temperature coefficient $(\mathrm{Q} 10) \geq 2-5$ are considered temperature dependent $[9,10]$. Thermoreceptors are sensitive to changes in temperature rather than to the value of the temperature itself, probably due to their characteristic strong adaptation. These receptors are classified into two groups depending on whether their discharge frequency increases when they are heated or cooled (Figure 1). Based on this classification, it is common to speak of four thermal sensations (cold -10 to $15^{\circ} \mathrm{C}$, cool $16-30{ }^{\circ} \mathrm{C}$, warm $31-42{ }^{\circ} \mathrm{C}$ and hot $43-60^{\circ} \mathrm{C}$ ), whereby cold and hot are potentially noxious and/or painful [11,12].

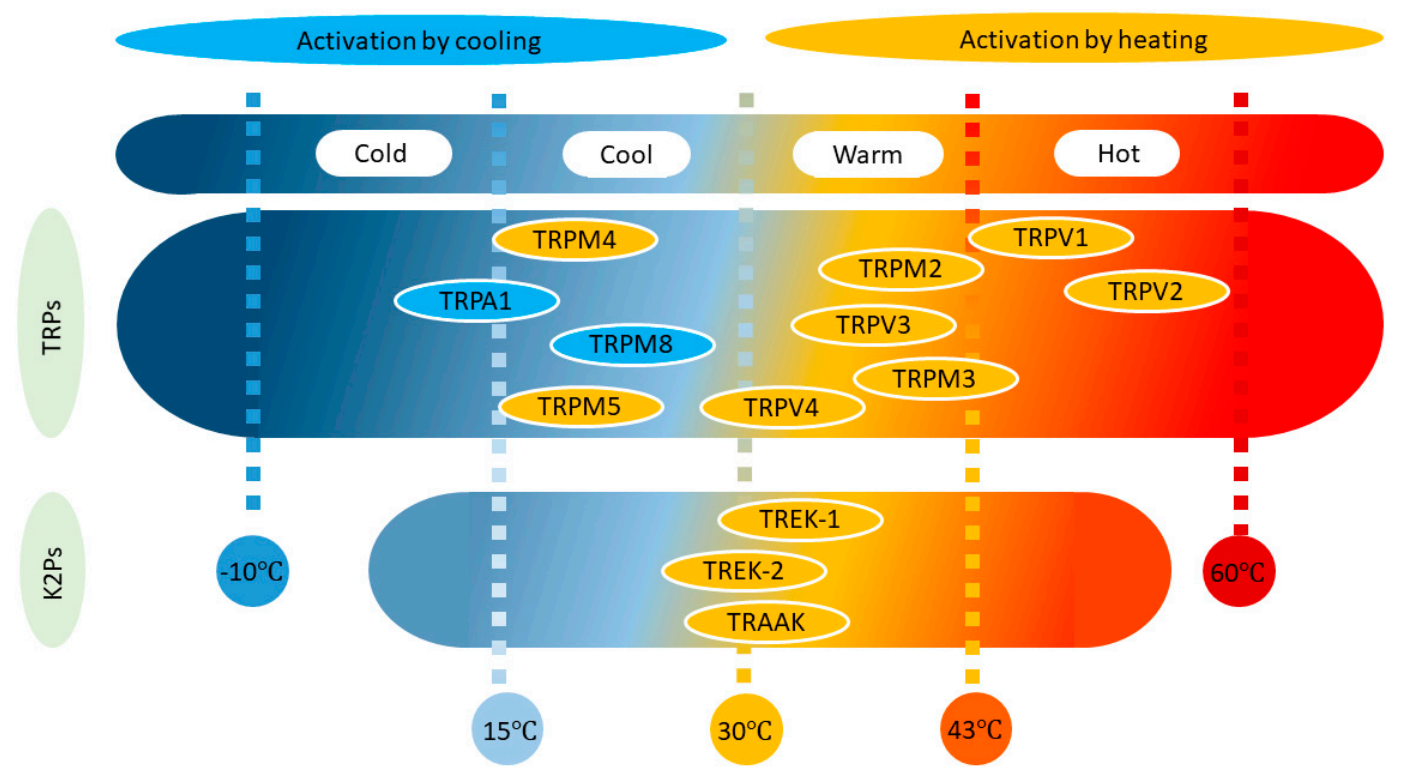

Figure 1. Distribution of transient receptor potential (TRP) and TWIK-related potassium (TREK) channels as a function of their temperature threshold. Note that while TREK channels are activated by increases in temperature (orange), TRP channels may also be activated by lowering the temperature (blue).

The modulation of TWIK-related potassium (TREK) channels by temperature has been touched on in several reviews [13-21], yet very few have dealt exclusively with this exciting topic [22]. Conversely, after transient receptor potential (TRP) channels sensitive to temperature were discovered, they were studied extensively to understand how thermal stimuli were transduced. Such interest led to the appearance of good reviews covering this issue [12,23-27]. In this review, we will focus on the less well-known role of TREK channels in thermosensation, and we will compare the behavior of these channels to that of TRP channels. Other thermosensitive proteins have also been described, like the $\mathrm{Na} / \mathrm{K}$ ATPase and ENaC channels, or P2X receptors, and while these should also receive attention, we consider this to fall beyond the scope of this review. Indeed, cell thermosensitivity seems to be governed by the interplay of a number of channel types, as reported in hypothalamic neurons [28].

\section{TREK Channels}

The TWIK-related potassium channel (TREK) subfamily belongs to the two-pore domain potassium channels family (K2P) and is comprised of three members: TREK1, TREK2, and TRAAK (TWIK-related arachidonic acid-activated potassium channel). These are background potassium channels characteristically modulated by several physical and chemical stimuli, such as membrane stretch, $\mathrm{pH}$, unsaturated fatty acids, general anesthetics, and temperature [29-34]. In general, TREK channels display very weak activity at room temperature and normal pressure, even when overexpressed in heterologous systems. However, their activity increases strongly when a number of different stimuli are applied, including an increase in temperature [31,35]. From a physiological 
point of view, it is important to note that at $37^{\circ} \mathrm{C}$, all three members of the TREK subfamily respond to stimuli ( $\mathrm{pH}$, membrane stretch, or arachidonic acid), much like they do at room temperature [36]. TREK channels may fulfil a dual role in the transmission of thermal pain. Thus, their strong activation by noxious heat results in an outward current that provokes membrane hyperpolarization and a reduction of thermoreceptor firing, provoking heat-pain relief. Conversely, inhibition of TREK channels by noxious cold should depolarize thermoreceptors and increase their excitability, cooperating in the transduction of noxious cold sensations (see Figure 2).

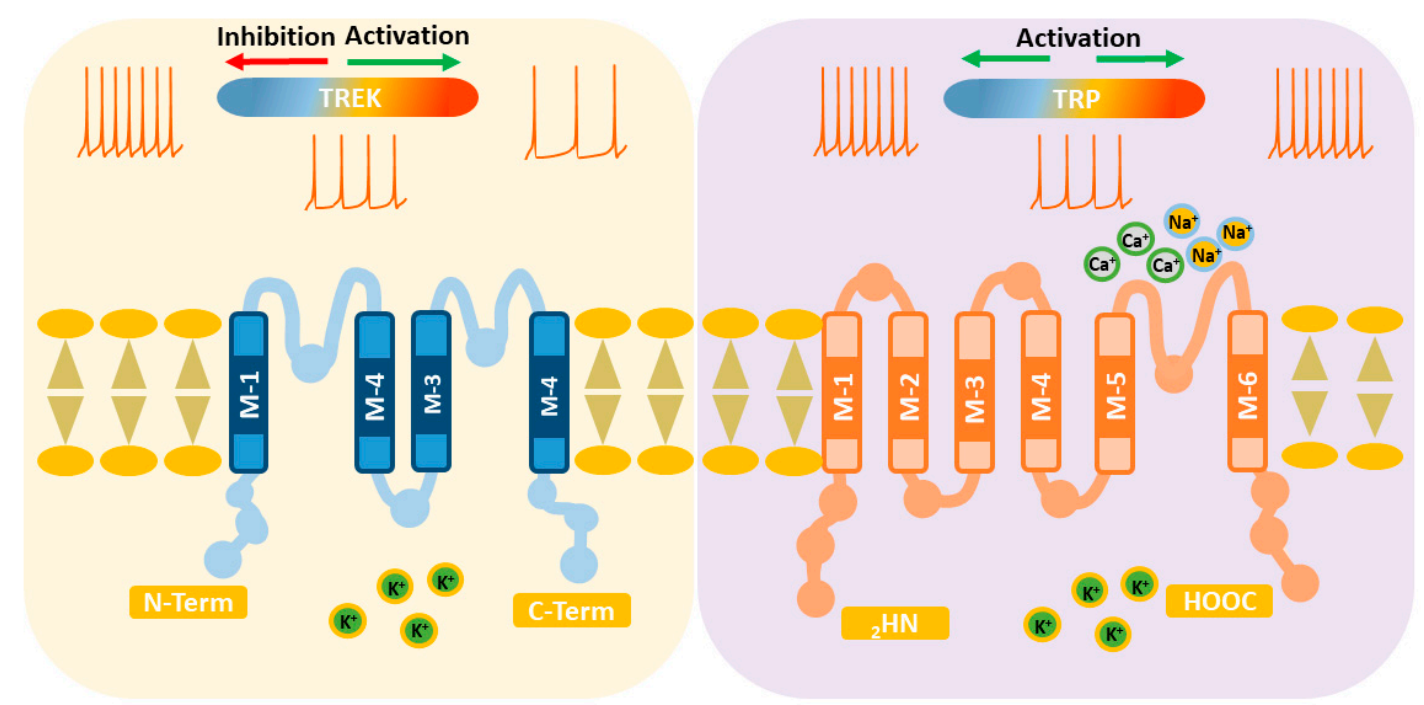

Figure 2. Proteins forming TREK channels have four transmembrane segments and two pore domains so that they assemble as dimers. Activation of TREK channels by increasing the temperature reduces the excitability of thermoreceptors (left). In contrast, TRP channels possess six transmembrane segments and only one pore domain, so that they are tetramers. Activation of TRPs increases the excitability of thermoreceptors, but some are activated by an increase and other by a decrease in temperature (right).

\subsection{TREK1}

Soon after their discovery, it was shown that TREK1 channels are strongly and reversibly activated by an increase in temperature when expressed in heterologous systems (cell line derived from kidney (COS) cells, oocytes) $[31,36]$. If we consider that these are mostly voltage-independent channels open at resting potentials, TREK1 channels should function as cold sensors because low temperatures would dampen their activity and depolarize these thermoreceptors (see Figure 2) [31]. Many authors have demonstrated that macroscopic TREK1 currents are strongly outwardly rectifying at room temperature $[29,30,32,37,38]$. While the outward current is not evident at $12{ }^{\circ} \mathrm{C}$, it is strongly enhanced at $37^{\circ} \mathrm{C}$, and the current progressively increases as the temperature gradually augments [31,39]. Indeed, the current increases around 7-fold with an increase of $10{ }^{\circ} \mathrm{C}$ in the range of 14 to 42 degrees, and importantly, maximal sensitivity ( 0.9 -fold per degree) was reached at nearly physiological temperatures, between 32 and $37^{\circ} \mathrm{C}$ [31]. The current induced by heating is also outwardly rectifying, and it reverses at potentials close to the equilibrium potential for potassium $\left(\mathrm{E}_{\mathrm{K}}\right)[31,36,40]$. In heterologous systems, the activation of TREK1 by temperature may be reversibly inhibited by cAMP, and this inhibition is suppressed by mutation of the C-terminal region that harbors a phosphorylation site for protein kinase A (PKA) [31]. Moreover, chicken embryonic atrial myocytes express TREK-like currents, and they have a resting membrane potential of around $-20 \mathrm{mV}$ in culture, which increases to $-70 \mathrm{mV}$ when the temperature rises to $35^{\circ} \mathrm{C}$, a change that was ascribed to the activation of TREK $1 / 2$ channels. In voltage-clamp, the outward current recorded at $+60 \mathrm{mV}$ increased 9-fold [35]. In fact, both TREK1 and TWIK-related arachidonic acid-activated potassium (TRAAK) channels have been proposed to shut down the firing of hippocampal neurons when the temperature rises too high [28]. 
The threshold for the activation of slowly conducting C-fibers by noxious heat $\left(30-50^{\circ} \mathrm{C}\right)$ recorded in a skin-nerve preparation decreases in TREK1 $\mathrm{KO}$ mice, and the range of activation of these fibers by heat corresponds closely to the range in which TREK 1 is activated $\left(30-45^{\circ} \mathrm{C}\right)$ [41]. The number of action potentials in response to a heating ramp $\left(30-50{ }^{\circ} \mathrm{C}\right)$ was higher in the $\mathrm{KO}$ mice, although the response of C-fibers to a cooling ramp $\left(32-10^{\circ} \mathrm{C}\right)$ was similar in native and $\mathrm{KO}$ mice [41]. Indeed, TREK1 KO mice were hypersensitive to thermal pain up to $50{ }^{\circ} \mathrm{C}$ but not at higher temperatures $\left(52-56{ }^{\circ} \mathrm{C}\right)$, indicating that TREK 1 channels may be important for the perception of low-threshold but not high-threshold thermal stimuli, for which TRP channels may be more important [41]. Accordingly, the proportion of small diameter, cultured, dorsal root ganglia (DRG) neurons that respond to noxious heat $(34 \%)$ increases in TREK1 KO $(64 \%)$ and TREK1/TRAAK KO $(74 \%)$ mice, as does the proportion of heat-responsive C-fibers in nerve-skin preparations from the single and double $\mathrm{KO}$ [42]. It is possible that TREK1 and TRAAK channels counteract the stimulatory effect of heat-activated TRP channels in pain transducing fibers when temperatures increase, such that the overall response may reflect a balance of the activity of these two functionally contrasting channel types. The threshold of thermoreceptors should certainly increase in the presence of TREK channels as temperatures increase.

Cooling of DRG neurons in culture from 32 to $20^{\circ} \mathrm{C}$ induces a depolarization of about $10 \mathrm{mV}$ and often the firing of action potentials, an effect shown to be due to the inhibition of a background potassium current $[41,43]$. Accordingly, the inhibition of a native TREK1-like current may underlie the excitation (depolarization and firing) produced by cold in small, cultured, trigeminal ganglion (TG) neurons (see Figure 2). Interestingly, cold induces subthreshold oscillations in cold-sensitive DRG neurons [44]. Transduction seems to be rather complex, involving the dampening of a hyperpolarization-activated cationic current and a permissive role for a slowly inactivating potassium current [44]. Interestingly, the TREK1/TRAAK double KO mutant shows a consistent cool allodynia, and oxaliplatin, a cancer therapy that causes peripheral nerve neuropathy, exacerbates cold sensitivity in many patients and animals, inducing allodynia to cool temperatures [45].

Neither the deletion of TREK1 or TRAAK increases the fraction of small DRG neurons sensitive to noxious cold stimuli (below $20^{\circ} \mathrm{C}$ and down to about $10^{\circ} \mathrm{C}$ ), although the TREK1/TRAAK KO and the triple TREK1/TREK2/TRAAK KO showed a significant increase in such neurons [42]. Similar results were obtained when recording C-fibers in a skin-nerve preparation, in which case the double KO C-fibers fired more strongly than the single TRAAK KO and wild-type fibers [42]. Oxaliplatin also induced hypersensitivity to noxious cold temperatures [45], while double and triple KO mice but not the TREK1 $\mathrm{KO}$ mice are hypersensitive to cold, which is not further affected by oxaliplatin. Hence, the deletion of two of the three TREK channels appears to be sufficient to reach maximal hypersensitization $[45,46]$. The neuroprotective agent riluzole induces an analgesic effect against painful cold in normal animals, but also in oxaliplatin pretreated TREK2 KO and TRAAK KO animals [46]. However, riluzole did not affect pain sensitivity in TREK1 KO animals treated with oxaliplatin, in animals treated with the TREK1 inhibitor spadin, or in untreated TREK1 KO mice or triple KO animals [46]. Similarly, a presumed TREK leak outward current recorded in DRG neurons was inhibited by riluzole and fluoxetine at 22 and $30{ }^{\circ} \mathrm{C}$ but not at $14^{\circ} \mathrm{C}$, probably because the current was already inhibited at low temperatures [47]. Together, these experiments suggest that TREK1 channels fulfil an essential role in the perception of noxious cold and that TREK1 and TRAAK channels work together in sensing cold [46].

Cell-attached patches demonstrated that the basal activity of expressed TREK1 channels is insignificant at room temperature, gradually increasing as the temperature rises (17-fold for an increase of $20^{\circ} \mathrm{C}$ ) and with a threshold around $25^{\circ} \mathrm{C}[31,36,48]$. The current activated by temperature also displays outward rectification and reverses around the equilibrium potential for $\mathrm{K}^{+}$[31], although the single-channel conductance remains unaffected [36]. TREK1-like channels naturally expressed in cardiac ventricular myocytes and DRGs, and recorded in cell-attached patches, do not open at $24^{\circ} \mathrm{C}$, yet they are very active at $37^{\circ} \mathrm{C}[36,48]$. Surprisingly, increases in temperature fail to modulate TREK1 activity in outside-out and inside-out patches, but under the same conditions, TREK1 is still strongly activated by arachidonic acid $[31,36]$. 
TREK1 channels are ideally positioned to act as thermosensors because they are expressed in structures clearly related to thermosensitivity and thermoregulation such as DRGs, the TG, nodose ganglia (NG), or the anterior and preoptic hypothalamus $[13,28,31,36,41,47-56]$.

\subsection{TREK2}

Heterologously expressed TREK2 channels also produce strong outward rectification when recorded in whole-cell configuration at room temperature [57-59], which increases greatly at temperatures around $37^{\circ} \mathrm{C}$ in several heterologous systems $[36,40,60]$. In COS cells, a small TREK2 current was observed at $0 \mathrm{mV}$ that augmented progressively with a gradual rise in temperature to about $40{ }^{\circ} \mathrm{C}$. Notwithstanding, the response of TREK2 to abrupt changes in temperature was rapid [36]. Importantly, the IVs of the TREK2 current at different temperatures $\left(24\right.$ and $\left.37^{\circ} \mathrm{C}\right)$ showed that the effect of temperature was not voltage dependent: both inward and outward currents increasing to the same degree. In this range of temperatures, the current increased 14 -fold per $10^{\circ} \mathrm{C}$, indicating a very strong temperature dependence that was even bigger than that of TREK1 [36]. Much like TREK1, TREK2 responds to temperature changes around the physiological range, with current activated reasonably well at $37^{\circ} \mathrm{C}$ and at resting membrane potential (RMP). Most experiments on TREK channels have been carried out at room temperature and at $0 \mathrm{mV}$. However, in the future these currents should be investigated using more physiological parameters, around a resting potential and $37^{\circ} \mathrm{C}$, providing a more precise idea of their role in the behavior of central neurons [14].

Cerebellar granule and DRG neurons expressed native TREK2-like channels with weak activity at $24{ }^{\circ} \mathrm{C}$ in cell-attached patches, yet when the temperature increased to 37 or $41{ }^{\circ} \mathrm{C}$ they became very active at all voltages $(-80$ to $+80 \mathrm{mV})[36,48]$. Moreover, cultured cortical astrocytes have TREK2-like whole-cell outward currents that are strongly enhanced in the temperature range of $23-40^{\circ} \mathrm{C}$. Interestingly, ischemia significantly augmented the outward current provoked by an increase in temperature in these astrocytes [61]. In addition, it was recently reported that TREK2 channels contribute about $10 \mathrm{mV}$ to the RMP of DRG neurons at about $30^{\circ} \mathrm{C}$ [62]. Furthermore, single TREK2 and triple TREK1/TREK2/TRAAK KO mice were more sensitive to warm temperatures $\left(40-42{ }^{\circ} \mathrm{C}\right)$ when tested with the tail-flick reflex [63].

Using a skin-nerve preparation, it was demonstrated that the proportion of heat-sensitive C-fibers and their activity (number of action potentials) increased in the TREK2 and triple KO mice when temperatures rose to noxious heat levels (ramped from 30 to $50^{\circ} \mathrm{C}$ ), whereas the temperature threshold for firing decreased [63]. At high temperatures (between 40 and $50^{\circ} \mathrm{C}$ ), the triple but not the single $\mathrm{KO}$ fibers were more active than their wild-type counterparts, indicating that TREK2 regulates C-fiber responses at temperatures below $40^{\circ} \mathrm{C}$, while at higher temperatures other TREK channels participate in these responses [63]. Both KOs suffered hyperalgesia at temperatures around $45^{\circ} \mathrm{C}$, but only the triple KO showed the same behavior above this temperature [63].

The withdrawal latency in the tail immersion test was clearly reduced in both the TREK2 KO and the triple $\mathrm{KO}$ mice when innocuous cooling temperatures were tested $\left(20-25^{\circ} \mathrm{C}\right)$. As such, the $\mathrm{KOs}$ show enhanced sensitivity to temperatures in the normal range and similar results were obtained in a temperature preference test [63]. The percentage of C-fibers responding to moderate cold $\left(30-21{ }^{\circ} \mathrm{C}\right)$ was clearly higher in single and triple KOs when compared to those recorded from the nerve-skin preparation of wild-type mice [63]. Interestingly, the cold threshold for C-fiber firing $\left(21^{\circ} \mathrm{C}\right)$ was lower in the triple $\mathrm{KO}\left(24^{\circ} \mathrm{C}\right)$ but not the TREK2 $\mathrm{KO}\left(23^{\circ} \mathrm{C}\right)$ mice [63]. Moreover, oxaliplatin induces mice to spend more time on a hot plate $\left(30^{\circ} \mathrm{C}\right)$ than on a cold plate $\left(20-25^{\circ} \mathrm{C}\right)$ when compared to untreated animals, indicating that neuropathic mice have enhanced sensitivity to moderate cold [63]. It has been suggested that TREK2 is implicated in the neuropathic hypersensitivity induced by this drug and indeed, oxaliplatin almost halved the TREK2 mRNA detected in DRG neurons [63]. Generally, the data suggest that TREK2 channels may be essential for the control of the C-fiber response to cold at moderate temperatures. The tail immersion test showed that triple $\mathrm{KO}$ mice were hypersensitive to noxious cold temperatures $\left(15-5{ }^{\circ} \mathrm{C}\right)$, while the single TREK2 $\mathrm{KO}$ mice behaved much like the 
wild-type mice. Moreover, very similar results were obtained in the nocifensive dynamic cold plate test [63]. Accordingly, it was suggested that TREK2 may not be important in noxious cold sensitivity but that it might be essential for thermoreception at moderate cool temperatures $\left(25-20^{\circ} \mathrm{C}\right)$ [63].

A clear, fast, and reversible increase in activity was also reported for single TREK 2 channels in cell-attached patches held at $-40 \mathrm{mV}$ when the temperature increased $\left(24\right.$ to $\left.37^{\circ} \mathrm{C}\right)$, with a threshold for this increase at $25^{\circ} \mathrm{C}$ (from $24^{\circ} \mathrm{C}$ ) and not affecting the conductance [36,48]. It should be noted that in these circumstances, the activity of TREK2 single channels was very low at $24{ }^{\circ} \mathrm{C}$ [36]. Significantly, neither TASK3 nor TRESK2 showed such dependence on temperature [36]. However, like TREK1, the activity of TREK2 in inside-out patches was not modified by changes in temperature (24 to $42{ }^{\circ} \mathrm{C}$ ) [36]. Finally, it is important to consider that TREK2 channels are expressed strongly in the DRG, TG, and hypothalamus $[36,47,48,51,52,55,56]$, yet less than TREK1 in the NG [49].

\subsection{TRAAK}

Much like the other members of the family, TRAAK currents showed a strong open-channel outward rectification when recorded in whole-cell configuration [64-66], and these currents increase strongly when the temperature rises $\left(24\right.$ to $\left.42{ }^{\circ} \mathrm{C}\right)$ [36]. Moreover, the percentage of small-diameter DRG neurons responding to noxious heat, in culture, is increased in TRAAK and TRAAK/TREK1 $\mathrm{KO}$ mice. Consistently in skin-nerve preparations, the percentage of fibers responding to heating $\left(30-50^{\circ} \mathrm{C}\right)$ and the number of action potentials in response to a heating ramp also clearly increases, while the firing threshold is reduced [42]. Notably, TRAAK and TRAAK/TREK1 KO mice suffer heat hyperalgesia when evaluated in the tail immersion test in the $46-50{ }^{\circ} \mathrm{C}$ range. Moreover, the double but not the single $\mathrm{KO}$ also shows hypersensitivity at higher temperatures $\left(52-56^{\circ} \mathrm{C}\right)$ in the hot plate test [42].

Knock-out of TRAAK did not modify the percentage of DRG neurons in culture that respond to noxious $\left(12{ }^{\circ} \mathrm{C}\right)$ cold [42]. Moreover, in the cold plate assay, TRAAK KO mice behave like wild-type mice, whereas TREK1/TRAAK KO mice are more sensitive to cooling in the 10 to $20^{\circ} \mathrm{C}$ range [42]. The activity of single TRAAK channels heterologously expressed in COS cells and recorded in cell-attached patches at $-40 \mathrm{mV}$ was very low at $24{ }^{\circ} \mathrm{C}$, yet it increased progressively as the temperature rose from 24 to $37^{\circ} \mathrm{C}$. The threshold for activity was around $30^{\circ} \mathrm{C}$, slightly higher than that reported for TREK 1 and TREK2 $[36,48]$. However, the behavior of TRAAK channels in inside-out patches mimics that of TREK1 and TREK2 such that their activity was not affected by changes in temperature (from 24 to $42^{\circ} \mathrm{C}$ ) [36]. Native TRAAK-like channels in DRG neurons displayed little activity at room temperature, but there was clear activity in all cell-attached patches at $37^{\circ} \mathrm{C}[36,48]$. Finally, TRAAK channels are clearly expressed in the hypothalamus, TG, and DRG $[28,36,47,48,51,52,55,56,66,67]$, yet they are only weakly expressed in the NG [13,49].

\subsection{Molecular Origin of Thermosensitivity}

When first discovered, mouse TREK1 was reported to have four transmembrane segments, two pore domains and a sequence of 370 aa [37]. The activation of heterologously expressed TREK1 currents by increasing temperature is unaffected by deletion of the cytoplasmic $\mathrm{N}$-terminal region. By contrast, partial deletion of the C-terminal region $(\Delta 103)$ or replacement of this region with that of TASK1 strongly dampens the activation of TREK1 by heat [31]. Sensitivity of the TREK1 channels to temperature can be eliminated by mutating helix 1 of the pore (G137I), suggesting that temperature affects the TREK1 and TREK2 channels by manipulating the C-type gate [22]. It was suggested that functional coupling between the C-terminal domain and the C-type gate through the M4 segment is crucial for the heat sensitivity of the TREK1 channel [22]. Thus, it is tempting to speculate that increasing the affinity of the C-terminal domain for phospholipids of the inner leaflet would increase the activity of TREK1 by heat, as proposed for other stimuli like stretch, PUFAs, phospholipids, or $\mathrm{pH}$. Conversely, dissociation of this domain from the membrane would result in TREK1 inhibition $[13,21,68,69]$. Surprisingly, replacement of the C-terminus of TREK2 with that of TASK3 did not reduce the sensitivity of the channel to changes 
in temperature in the range of 24 to $37^{\circ} \mathrm{C}$ under similar conditions, although it became insensitive to $\mathrm{pH}$ and arachidonic acid [36]. Heat enhances the activity of TREK1, TREK2, and TRAAK in whole-cell and cell-attached recordings, yet not in outside- and inside-out patches, indicating that the integrity of the cell, and probably also a second messenger, are necessary for this modulation [31,36]. The contribution of TREK channels to maintaining the RMP has often been questioned; however, this assertion is mostly based on experiments carried out at room temperature. Thus, new experiments should be performed at physiological temperatures to ascertain the role of these channels on both the RMP and neuronal excitability.

\section{TRP Channels}

Six transient receptor potential (TRP) channels are considered thermosensors, four of them responding to heat and two to cool $[11,26]$. Temperature-sensitive TRP channels (Thermo-TRP) are extremely dependent on temperature, showing very high Q10 values $(>20)$ [70].

\subsection{Heat-Sensitive TRP Channels}

Four TRP subtypes are activated by an increase in temperature (Figure 1). Two of them respond to warm stimuli (TRPV4 Warm $>27^{\circ} \mathrm{C}$ and TRPV3 Warm $>34{ }^{\circ} \mathrm{C}$ ), and the other two to hot-painful stimuli (TRPV1 Hot $>43^{\circ} \mathrm{C}$ and TRPV2 Hot $>52^{\circ} \mathrm{C}$ ) [23,25].

TRPV1s are voltage- and temperature-dependent channels that display outward rectification when expressed in human embryonic kidney (HEK) cells and that are strongly enhanced by heating (to $48^{\circ} \mathrm{C}$ ) and by capsaicin $[71,72]$. At room temperature, the current passing through these channels is negligible below $0 \mathrm{mV}$, but at $42{ }^{\circ} \mathrm{C}$ the channel activates more or less between -100 and $+50 \mathrm{mV}$ [71]. These cationic channels are ten times more permeable to $\mathrm{Ca}^{2+}$ than to $\mathrm{Na}^{+}\left(\mathrm{P}_{\mathrm{Ca}} / \mathrm{P}_{\mathrm{Na}} \sim 10\right)$ and are thought to be sensors for noxious heat but not activated by innocuous heat [24,72-74]. Indeed, the response to noxious heat in mice lacking TRPV1 (KO) or DRG neurons was clearly weaker, although other channels may also contribute to the perception of noxious thermal stimuli because heat still evokes receptor activation in several preparations $[23,25,73]$. The NG sensory neurons that innervate the lungs produce an inward current in response to an elevation in temperature (from 23 to $41^{\circ} \mathrm{C}$, with a threshold around $35^{\circ} \mathrm{C}$ and a Q10 of about 30 in the range of $35-41^{\circ} \mathrm{C}$ ) as well as membrane depolarization and action potential firing. This response was ascribed to the presence of TRPV1 channels, even though the participation of TRPV2-4 could not be ruled out [10]. We obtained similar results with NG neurons in culture, although these were slightly more complex because a hyperpolarization was observed before the depolarization and firing (unpublished data). It is interesting to note that inflammatory mediators like ATP and bradykinin strongly reduce the threshold of TRPV1 activation $\left(30^{\circ} \mathrm{C}\right)$ such that warm temperatures become painful [23]. TRPV1 is strongly expressed in small-diameter sensory neurons of the DRG, TG, and NG, but also in the hypothalamus [10,23,72], sites where they may exert an important role in thermoreception.

TRPV2 is activated at extremely high temperatures $\left(52^{\circ} \mathrm{C}\right)$, although it is not affected by capsaicin and shows an outwardly rectifying IV curve and a $\mathrm{P}_{\mathrm{Ca}} / \mathrm{P}_{\mathrm{Na}} \sim 3[24,70,75,76]$. This channel has a $\mathrm{Q} 10$ of around 100, and it is thought that the temperatures that activate TRPV2 are more harmful than those that activate TRPV1 [77]. These channels are strongly expressed by myelinated medium-large diameter DRG neurons (A $\delta$ and $A \beta$ ), as well as in the hypothalamus and in the NG $[10,78]$.

TRPV3 channels are activated at warm, close to hot, temperatures (around $34-39{ }^{\circ} \mathrm{C}$, with a $\mathrm{Q} 10$ around 6), generating currents with pronounced outward rectification and a $\mathrm{P}_{\mathrm{Ca}} / \mathrm{P}_{\mathrm{Na}} \sim 12$ [24,79]. They are capsaicin-insensitive channels but stimulated by camphor [79], and they are thought to be involved in thermosensation and thermal nociception [79,80]. Indeed, it has been suggested that TRPV3 channels contribute more to the speed with which mice select a more comfortable temperature than to the choice of the value of the temperature itself. By contrast, TRPV4 channels are more likely to be involved in choosing the preferred temperature from a non-painful range [26]. Interestingly, it was proposed that TRPV3 channels transmit thermal stimuli through skin keratinocytes, which in turn will 
transmit this information to sensory endings [25,81]. TRPV3 channels are expressed in sensory DRG and NG neurons but also in the hypothalamus. Interestingly, they co-localize with TRPV1 in DRG neurons $[10,82]$.

TRPV4 are cationic $\left(\mathrm{P}_{\mathrm{Ca}} / \mathrm{P}_{\mathrm{Na}} \sim 6[24,76]\right)$ channels activated at even lower warm temperatures (around $27^{\circ} \mathrm{C}$, with a Q10 of about 10 ), generating outwardly rectifying currents and responding dynamically to temperature changes in the physiological range [82]. These channels were proposed to play a role in thermosensation and thermoregulation $[82,83]$, although some authors were unable to activate these channels by increasing the temperature. Similarly, some behavioral studies reported a reduced response to temperature changes in TRPV4 KO mice, a behavior that was less clear in other studies $[84,85]$. Much like TRPV3, the expression of these channels in keratinocytes was proposed to play an important role in the transmission of thermal information, which probably contributed to the controversy generated $[25,26,83]$. The sensitivity of this channel to temperature is lost in excised patches, suggesting that it requires a soluble intracellular factor [86]. TRPV4 channels are expressed in DRG, TG, NG, and preoptic/anterior hypothalamic [10,82] neurons, although in the hypothalamus they seem to be expressed in terminals rather than in the soma, such that their role in body thermoregulation is unclear [28].

TRPM2 $\left(>35^{\circ} \mathrm{C}\right), \mathrm{TRPM} 3\left(>40^{\circ} \mathrm{C}\right), \mathrm{TRPM} 4\left(>15^{\circ} \mathrm{C}\right)$, and TRPM5 $\left(>15^{\circ} \mathrm{C}\right)$ are channels that can also be activated by warming (Figure 1), yet they have received less attention, probably because it was initially thought that they were not expressed by somatosensory neurons or keratinocytes $[12,26,87]$. TRPM2 is voltage-insensitive, shows a $\mathrm{P}_{\mathrm{Ca}} / \mathrm{P}_{\mathrm{Na}} \sim 1[24,76]$, activates at $35^{\circ} \mathrm{C}$, and has a $\mathrm{Q} 10$ of around $15[12,88]$. TRPM3 is expressed broadly, generating an outwardly rectifying current, having a $\mathrm{P}_{\mathrm{Ca}} / \mathrm{P}_{\mathrm{Na}}$ between 0.1 and 10 [24,76], and activating at $>40{ }^{\circ} \mathrm{C}$ with a Q10 of 7 [89]. It is important to say that TRPM3 has been described as part of a triad of TRPs, together with TRPV1 and TRPA1, involved in the transduction of acute noxious heat in mice [90]. The combined ablation of these channels (triple KO) was necessary for the complete reduction of acute noxious sensing; single or double KO combinations resulted in deficits in heat responsiveness, but mice still conserved vigorous withdrawal responses to noxious heat [90]. Heat activation of TRPM2 and TRPM5 was obtained in inside-out patches, suggesting a membrane-delimited mechanism. Interestingly, TRPM2 activation seems to result from the increase in the IV slope while that of TRPM4 and TRPM5 results from a shift of the activation curve to negative potentials $[87,88]$. These last two channels are essentially not permeable to calcium $[12,24]$.

\subsection{Cold-Sensitive TRP Channels}

Two TRP channels are activated by decreases in temperature (Figure 1$)$, TRPM $8\left(<25^{\circ} \mathrm{C}\right)$ activates in the cool range while TRPA $1\left(<18^{\circ} \mathrm{C}\right)$ senses cold-painful temperatures $[23,25,91,92]$. Similarly, cool fibers (A $\delta$ and $\mathrm{C}$ ) have activation thresholds at about $30^{\circ} \mathrm{C}$ and cold fibers $(\mathrm{C})$ have activation thresholds $<20^{\circ} \mathrm{C}$. Accordingly, two populations of TG neurons were described in terms of their activation threshold when temperatures decrease: 30 and $20^{\circ} \mathrm{C}$ for a low and high threshold, respectively [93]. In general, cold fibers fire continuously at normal skin temperatures and they increase their firing frequency when the skin is cooled down, or they shut down when the skin is warmed. In addition, cold fibers can adapt to small decreases in temperature [25].

TRPM8 channels are voltage-dependent cationic channels that are permeable to $\mathrm{Na}^{+}, \mathrm{K}^{+}, \mathrm{Cs}^{-}$, and $\mathrm{Ca}^{2+}\left(\mathrm{P}_{\mathrm{Ca}} / \mathrm{P}_{\mathrm{Na}} \sim 3\right)[24,92,94]$. When expressed in HEK cells and recorded in whole-cell configuration, they show a voltage-dependent outwardly rectifying current that strongly increases upon cooling from 30 to $15^{\circ} \mathrm{C}$ or through the application of menthol. Importantly, both basal and cold-stimulated currents reverse around $0 \mathrm{mV}$ and were almost negligible below this potential [9,71,92]. Cooling CHO cells expressing TRPM8 (in the range of 25 to $15^{\circ} \mathrm{C}$ ) also induces an increase in intracellular calcium [92], and the Q10 in the range of 25 to $18{ }^{\circ} \mathrm{C}$ is around 24 . The effect of temperature is due to an increase in the open probability and a shift in the conductance-voltage relationships along the voltage axis [9]. Similar results were obtained in inside-out macropatch recordings, although the stimulation occurred at lower temperatures, suggesting that the integrity of the cell is important but not indispensable [71]. 
The role of this channel as a detector of painful cold has been questioned in experiments on KO mice, but nevertheless, it is accepted that it is an important cold sensor in vagal, TG, and especially DRG afferents [95-98]. It was predicted that cold transduction may require the activation and inhibition of several different ion channels (see Figure 3), such as TRP, TREK, and ENaC channels [93]. If this were the case, TRP channels would probably be more important in the noxious-cold range, whereas TREK channels might participate more strongly in the cool range of temperatures (Figure 1). TRPM8 is expressed in small-diameter DRG and TG neurons, presumably thermoreceptors, yet it seems not to co-localize with TRPV1 $[25,92,94]$.

TRPA1 is activated by lower temperatures than TRPM $8\left(<18^{\circ} \mathrm{C}\right)$, and while it would be expected to be involved in cold nociception, this is not that clear [91,98-101]. TRPA1 generates an outward rectifying cationic current, both in control conditions and when cold activated (about $10{ }^{\circ} \mathrm{C}$ ), with similar permeability for $\mathrm{Ca}^{2+}$ and $\mathrm{Na}^{+}\left(\mathrm{P}_{\mathrm{Ca}} / \mathrm{P}_{\mathrm{Na}} \sim 1\right)[24,76,91]$. Cinnamaldehyde can selectively activate currents through this channel in native DRG neurons, as can bradykinin (when co-expressed with BK receptors), strongly suggesting a role in sensing nociceptive stimuli [91]. However, TRPA1 KO mice do not seem to have difficulties in sensing cold stimuli through the skin, while the response of TRPM KO mice to cold is significantly dampened $[96,97,101]$. By contrast, about $50 \%$ of NG neurons in culture were activated by cooling $\left(<24^{\circ} \mathrm{C}\right)$, mainly through TRPA1 channel activation (increase in $[\mathrm{Ca}]_{\mathrm{i}}$, depolarization, and AP firing). Interestingly, about $10 \%$ of the NG neurons responded to cold through a TRPA1- and Ca-independent pathway [95]. TRPA1 often co-localizes with TRPV1, and in fact, this could explain the paradoxical hot sensation experienced with an extremely cold stimulus [23,100]. Interestingly, most NG neurons sensitive to cold are also sensitive to heat [95]. TRPA1 is expressed in DRG and TGs, while TRPA1 and TRPM8 are not co-expressed in DRG neurons [91,99], but they are in TG neurons [90]. In summary, the data available suggest that TRPA1 is the principal ion channel involved in cold sensation in visceral (NG) neurons, while TRPM8 would fulfil the same role in somatic neurons [95].

\subsection{Molecular Origin of Thermosensitivity}

The mechanism by which temperature modulates TRP channels is still unclear, yet several hypotheses have been proposed: (1) changes in temperature could produce a ligand that binds to a receptor and affects the channel; (2) changes in temperature could produce a structural change in the channel that provokes its opening; (3) temperature changes could affect the structure of the membrane, causing changes in tension that would in turn affect ion channels. Because capsaicin induces burning pain, it has been hypothesized that both capsaicin and heat may use a common mechanism to activate TRPV1 and produce pain. Both stimuli affect excised patches, and in general, it is accepted that TRPV1 is directly activated by noxious-heat, so that it can be considered a true heat sensor [23].

The fact that TRPM 8 can be activated by cooling in inside-out patches suggests that the mechanism is membrane delimited, also arguing against the participation of a second messenger pathway [71]. Notwithstanding, inhibition of phospholipase $C$ strongly dampened the increase in calcium provoked by cold stimuli in TRPM8-expressing CHO cells [91]. Cooling activates TRPM8-expressed channels by causing a shift in the voltage dependence of activation to negative values, and the same mechanism is responsible for the activation of TRPV1 by heat $[9,11,71]$ but not the activation of TRPM2 [88]. It has been proposed that temperature induces large rearrangements of the protein and thus, the existence of a temperature-sensing domain or "temperature sensor" in the structure of TRPM8 channels [9]. Much like for TRPM8, inhibition of phospholipase $\mathrm{C}$ strongly reduces the increase in calcium provoked by cold stimuli in TRPA1-expressing CHO cells [90]. 

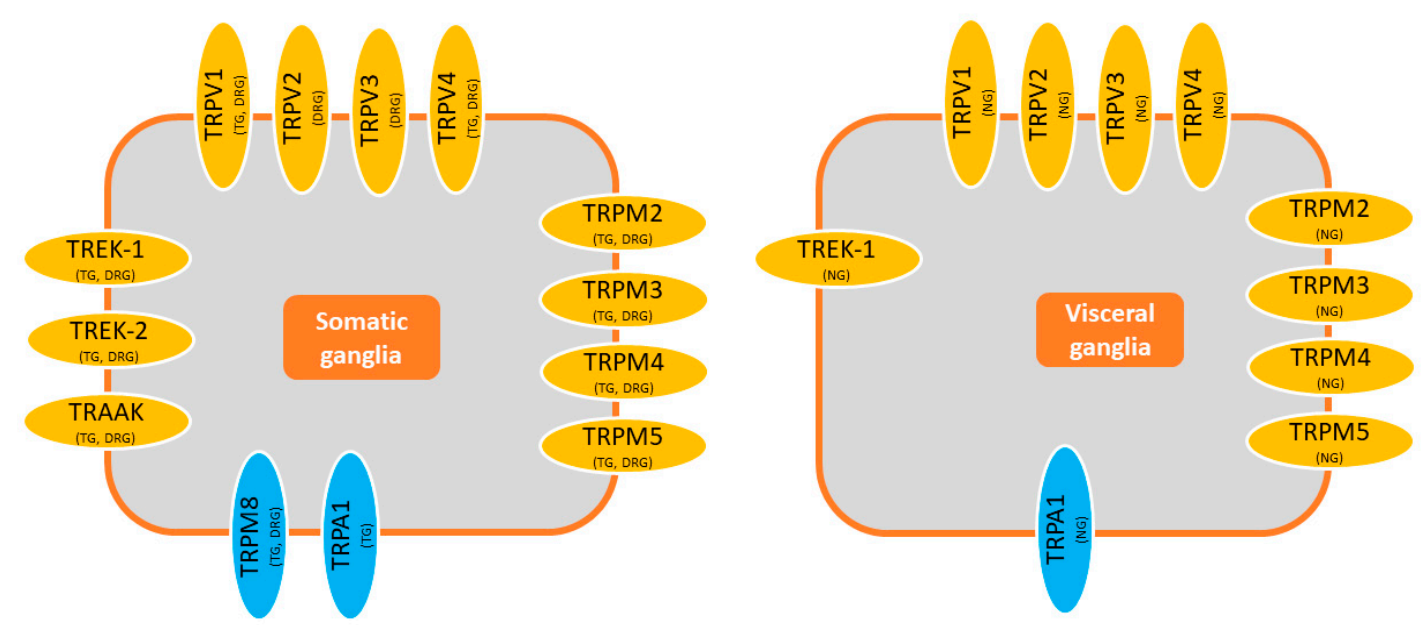

Figure 3. Most temperature-modulated channels are expressed in both somatic and visceral afferents. The expression of TREK2, TRAAK, and TRPM8 in visceral ganglia seems to be low when compared with other channels; however, colocalization of all these channels in the same neuron should be investigated in order to have a real picture of their relative importance in temperature sensing.

\section{Conclusions}

There is already sufficient data supporting the role of TREK and TRP channels in two fundamental aspects of the response to temperature. On the one hand, they are responsible for capturing the thermal sensation at the peripheral level, acting as thermosensors in thermoreceptive neurons or keratinocytes. On the other hand, yet no less important, they help regulate body temperature and allow neurons in the hypothalamus to become internal thermoreceptors. There are several important differences between the two main types of thermosensor channels that have been reviewed in this article (see Figure 2). First, TREKs are potassium channels with negative reversal potentials, such that their activation would result in a reduction in thermoreceptor activity. By contrast, as the reversal potential of TRPs (cationic channels) is close to $0 \mathrm{mV}$, their activation will result in increased thermoreceptor excitability. Second, the three TREK channels appear to increase their open probability as temperatures increase, while there are two possible situations in the case of TRPs: one in which its activity increases by increasing the temperature; and another in which activity increases when the temperature decreases (Figure 2). Although the activation of these channels generates opposing effects on thermoreceptors (depolarization versus hyperpolarization), the information available to date regarding the participation of TRP and TREK channels in thermosensitivity strongly suggests that both types of channels collaborate and complement each other to generate the sensations of heat, cold, and thermal pain. In support of this hypothesis, TREK and TRP channels are very often co-expressed in thermoreceptors and other sensory neurons [55,102]. TRP channels are generally accepted as the primary thermosensors; however, several lines of evidence indicate that other channels are necessary to explain the full plethora of mechanisms involved in thermosensation. TREK2 channels appear to be important in thermoreception at moderate temperatures and sensing innocuous cold but not aversive cold, while TREK1 and TRAAK acting together may be important in sensing painful cold.

Author Contributions: Conceptualization, J.A.L.; validation, J.A.L.; investigation, J.A.L., L.R.-R., S.H.-P.; resources, J.A.L.; writing of original draft, J.A.L., L.R.-R., S.H.-P.; review and editing of manuscript, J.A.L., L.R.-R., S.H.-P.; visualization, J.A.L., L.R.-R., S.H.-P.; supervision, J.A.L.; funding acquisition, J.A.L.

Funding: The work in our group was funded by grants to J.A.L. from the Spanish Government (Secretaría de Estado de Investigación, Desarrollo e Innovación, MINECO, BFU2014-58999-P), the Galician Government (Consellería de Cultura, Educación e Ordenación Universitaria, Xunta de Galicia, GPC2015/022), and the European Regional Development Fund (FP7-316265-BIOCAPS). This work was also partially supported by FEDER Funds.

Conflicts of Interest: The authors have no conflicts of interest to declare. The funding agencies played no role in the design of the study; in the collection, analyses, or interpretation of any data; in the writing of the manuscript, or in the decision to publish the results. 


\section{Abbreviations}

$\begin{array}{ll}\text { COS } & \text { Cell line derived from kidney } \\ \text { DRG } & \text { Dorsal root ganglion } \\ \text { HEK } & \text { Human embryonic kidney } \\ \text { K2P } & \text { Two-pore domain potassium channels } \\ \text { NG } & \text { Nodose ganglion } \\ \text { NS } & \text { Nervous system } \\ \text { PKA } & \text { Protein kinase A } \\ \text { TG } & \text { Trigeminal ganglion } \\ \text { TRAAK } & \text { TWIK-related arachidonic acid-activated potassium channel } \\ \text { TREK } & \text { TWIK-related potassium channel } \\ \text { RMP } & \text { Resting membrane potential }\end{array}$

\section{References}

1. Morris, N.B.; Filingeri, D.; Halaki, M.; Jay, O. Evidence of viscerally-mediated cold-defence thermoeffector responses in man. J. Physiol. 2017, 595, 1201-1212. [CrossRef] [PubMed]

2. Nakamura, K. Central circuitries for body temperature regulation and fever. Am. J. Physiol. Regul. Integr. Comp. Physiol. 2011, 301, R1207-R1228. [CrossRef]

3. Yu, Y.; Hill, A.P.; McCormick, D.A. Warm body temperature facilitates energy efficient cortical action potentials. PLoS Comput. Biol. 2012, 8, e1002456. [CrossRef]

4. Gasser, H.S. Unmedullated fibers originating in dorsal root ganglia. J. Gen. Physiol. 1950, 33, 651-690. [CrossRef] [PubMed]

5. Prosser, C.L. Action potentials in the nervous system of the crayfish: IV. influence of temperature on nerve impulses arising "spontaneously" in abdominal ganglia. J. Gen. Physiol. 1935, 19, 65-73. [CrossRef] [PubMed]

6. Latorre, R.; Hidalgo, M.C. Effect of temperature on resting potential in giant axons of squid. Nature 1969, 221, 962-963. [CrossRef]

7. Hodgkin, A.L.; Katz, B. The effect of temperature on the electrical activity of the giant axon of the squid. J. Physiol. 1949, 109, 240-249. [CrossRef] [PubMed]

8. Belluzzi, O.; Sacchi, O. A quantitative description of the sodium current in the rat sympathetic neurone. J. Physiol. 1986, 380, 275-291. [CrossRef] [PubMed]

9. Brauchi, S.; Orio, P.; Latorre, R. Clues to understanding cold sensation: Thermodynamics and electrophysiological analysis of the cold receptor TRPM8. Proc. Natl Acad Sci USA 2004, 101, 15494-15499. [CrossRef]

10. Ni, D.; Gu, Q.; Hu, H.Z.; Gao, N.; Zhu, M.X.; Lee, L.Y. Thermal sensitivity of isolated vagal pulmonary sensory neurons: Role of transient receptor potential vanilloid receptors. Am. J. Physiol. Regul. Integr. Comp. Physiol. 2006, 291, R541-R550. [CrossRef] [PubMed]

11. Pongs, O. TREKing noxious thermosensation. EMBO J. 2009, 28, 1195-1196. [CrossRef]

12. Tan, C.H.; McNaughton, P.A. TRPM2 and warmth sensation. Pflugers Arch.-Eur J. Physiol. 2018, 470, 787-798. [CrossRef]

13. Lamas, J.A. Mechanosensitive K2P channels, TREKking through the autonomic nervous system. In Mechanically gated channels and their regulation; Kamkin, A., Lozinsky, I., Eds.; Springer Science+Business Media: Dordrecht, The Netherlands, 2012; Volume 6, pp. 35-68.

14. Lotshaw, D.P. Biophysical, pharmacological, and functional characteristics of cloned and native mammalian two-pore domain K+ channels. Cell Biochem. Biophys. 2007, 47, 209-256. [CrossRef]

15. Patel, A.J.; Honore, E. Properties and modulation of mammalian 2P domain K+ channels. Trends Neurosci. 2001, 24, 339-346. [CrossRef]

16. Noel, J.; Sandoz, G.; Lesage, F. Molecular regulations governing TREK and TRAAK channel functions. Channels (Austin) 2011, 5, 402-409. [CrossRef] [PubMed]

17. Enyedi, P.; Czirjak, G. Molecular background of leak K+ currents: Two-pore domain potassium channels. Physiol. Rev. 2010, 90, 559-605. [CrossRef] 
18. Dedman, A.; Sharif-Naeini, R.; Folgering, J.H.; Duprat, F.; Patel, A.; Honore, E. The mechano-gated K(2P) channel TREK-1. Eur. Biophys. J. 2009, 38, 293-303. [CrossRef] [PubMed]

19. Sabbadini, M.; Yost, C.S. Molecular biology of background K+ channels: Insights from K2P knockout mice. J. Mol. Biol. 2009, 385, 1331-1344. [CrossRef]

20. Bayliss, D.A.; Barrett, P.Q. Emerging roles for two-pore-domain potassium channels and their potential therapeutic impact. Trends Pharmacol. Sci. 2008, 29, 566-575. [CrossRef]

21. Honore, E. The neuronal background K2P channels: Focus on TREK1. Nat. Rev. Neurosci. 2007, 8, $251-261$. [CrossRef]

22. Schneider, E.R.; Anderson, E.O.; Gracheva, E.O.; Bagriantsev, S.N. Temperature sensitivity of two-pore (K2P) potassium channels. Curr. Top. Membr. 2014, 74, 113-133.

23. Tominaga, M.; Caterina, M.J. Thermosensation and pain. J. Neurobiol. 2004, 61, 3-12. [CrossRef] [PubMed]

24. Nilius, B.; Voets, T. TRP channels: A TR(I)P through a world of multifunctional cation channels. Pfugers Arch.-Eur. J. Physiol. 2005, 451, 1-10. [CrossRef] [PubMed]

25. Dhaka, A.; Viswanath, V.; Patapoutian, A. Trp ion channels and temperature sensation. Annu. Rev. Neurosci. 2006, 29, 135-161. [CrossRef]

26. Caterina, M.J. Transient receptor potential ion channels as participants in thermosensation and thermoregulation. Am. J. Physiol. Regul. Integr. Comp. Physiol. 2007, 292, R64-R76. [CrossRef] [PubMed]

27. Mazzone, S.B.; Undem, B.J. Vagal Afferent Innervation of the Airways in Health and Disease. Physiol. Rev. 2016, 96, 975-1024. [CrossRef] [PubMed]

28. Wechselberger, M.; Wright, C.L.; Bishop, G.A.; Boulant, J.A. Ionic channels and conductance-based models for hypothalamic neuronal thermosensitivity. Am. J. Physiol. Regul. Integr. Comp. Physiol. 2006, 291, R518-R529. [CrossRef]

29. Patel, A.J.; Honore, E.; Maingret, F.; Lesage, F.; Fink, M.; Duprat, F.; Lazdunski, M. A mammalian two pore domain mechano-gated S-like K+ channel. EMBO J. 1998, 17, 4283-4290. [CrossRef]

30. Maingret, F.; Patel, A.J.; Lesage, F.; Lazdunski, M.; Honore, E. Mechano- or acid stimulation, two interactive modes of activation of the TREK-1 potassium channel. J. Biol. Chem. 1999, 274, 26691-26696. [CrossRef]

31. Maingret, F.; Lauritzen, I.; Patel, A.J.; Heurteaux, C.; Reyes, R.; Lesage, F.; Lazdunski, M.; Honore, E. TREK-1 is a heat-activated background $\mathrm{K}+$ channel. EMBO J. 2000, 19, 2483-2491. [CrossRef]

32. Maingret, F.; Patel, A.J.; Lesage, F.; Lazdunski, M.; Honore, E. Lysophospholipids open the two-pore domain mechano-gated K(+) channels TREK-1 and TRAAK. J. Biol. Chem. 2000, 275, 10128-10133. [CrossRef]

33. Sandoz, G.; Thummler, S.; Duprat, F.; Feliciangeli, S.; Vinh, J.; Escoubas, P.; Guy, N.; Lazdunski, M.; Lesage, F. AKAP150, a switch to convert mechano-, $\mathrm{pH}$ - and arachidonic acid- sensitive TREK K+ channels into open leak channels. EMBO J. 2006, 25, 5864-5872. [CrossRef]

34. Franks, N.P.; Honore, E. The TREK K2P channels and their role in general anaesthesia and neuroprotection. Trends Pharmacol. Sci. 2004, 25, 601-608. [CrossRef]

35. Zhang, H.; Shepherd, N.; Creazzo, T.L. Temperature-sensitive TREK currents contribute to setting the resting membrane potential in embryonic atrial myocytes. J. Physiol. 2008, 586, 3645-3656. [CrossRef]

36. Kang, D.; Choe, C.; Kim, D. Thermosensitivity of the two-pore domain K+ channels TREK-2 and TRAAK. J. Physiol. 2005, 564, 103-116. [CrossRef]

37. Fink, M.; Duprat, F.; Lesage, F.; Reyes, R.; Romey, G.; Heurteaux, C.; Lazdunski, M. Cloning, functional expression and brain localization of a novel unconventional outward rectifier $\mathrm{K}+$ channel. EMBO J. 1996, 15, 6854-6862. [CrossRef] [PubMed]

38. Duprat, F.; Lesage, F.; Patel, A.J.; Fink, M.; Romey, G.; Lazdunski, M. The neuroprotective agent riluzole activates the two P domain K(+) channels TREK-1 and TRAAK. Mol. Pharmacol. 2000, 57, 906-912. [PubMed]

39. Cohen, A.; Sagron, R.; Somech, E.; Segal-Hayoun, Y.; Zilberberg, N. Pain-associated signals, acidosis and lysophosphatidic acid, modulate the neuronal K(2P)2.1 channel. Mol. Cell Neurosci. 2009, 40, 382-389. [CrossRef] [PubMed]

40. Kreneisz, O.; Benoit, J.P.; Bayliss, D.A.; Mulkey, D.K. AMP-activated protein kinase inhibits TREK channels. J. Physiol. 2009, 587, 5819-5830. [CrossRef] 
41. Alloui, A.; Zimmermann, K.; Mamet, J.; Duprat, F.; Noel, J.; Chemin, J.; Guy, N.; Blondeau, N.; Voilley, N.; Rubat-Coudert, C.; et al. TREK-1, a K+ channel involved in polymodal pain perception. EMBO J. 2006, 25, 2368-2376. [CrossRef]

42. Noël, J.; Zimmermann, K.; Busserolles, J.; Deval, E.; Alloui, A.; Diochot, S.; Guy, N.; Borsotto, M.; Reeh, P.; Eschalier, A.; et al. The mechano-activated $\mathrm{K}+$ channels TRAAK and TREK-1 control both warm and cold perception. EMBO J. 2009, 28, 1308-1318. [CrossRef] [PubMed]

43. Reid, G.; Flonta, M.L. Cold transduction by inhibition of a background potassium conductance in rat primary sensory neurones. Neurosci. Lett. 2001, 297, 171-174. [CrossRef]

44. Viana, F.; de la Pena, E.; Belmonte, C. Specificity of cold thermotransduction is determined by differential ionic channel expression. Nat. Neurosci. 2002, 5, 254-260. [CrossRef] [PubMed]

45. Descoeur, J.; Pereira, V.; Pizzoccaro, A.; Francois, A.; Ling, B.; Maffre, V.; Couette, B.; Busserolles, J.; Courteix, C.; Noel, J.; et al. Oxaliplatin-induced cold hypersensitivity is due to remodelling of ion channel expression in nociceptors. EMBO Mol. Med. 2011, 3, 266-278. [CrossRef] [PubMed]

46. Poupon, L.; Lamoine, S.; Pereira, V.; Barriere, D.A.; Lolignier, S.; Giraudet, F.; Aissouni, Y.; Meleine, M.; Prival, L.; Richard, D.; et al. Targeting the TREK-1 potassium channel via riluzole to eliminate the neuropathic and depressive-like effects of oxaliplatin. Neuropharmacology 2018, 140, 43-61. [CrossRef] [PubMed]

47. Viatchenko-Karpinski, V.; Ling, J.; Gu, J.G. Characterization of temperature-sensitive leak K(+) currents and expression of TRAAK, TREK-1, and TREK2 channels in dorsal root ganglion neurons of rats. Mol. Brain 2018, 11, 40. [CrossRef]

48. Kang, D.; Kim, D. TREK-2 (K2P10.1) and TRESK (K2P18.1) are major background K+ channels in dorsal root ganglion neurons. Am. J. Physiol. Cell Physiol. 2006, 291, C138-C146. [CrossRef]

49. Cadaveira-Mosquera, A.; Pérez, M.; Reboreda, A.; Rivas-Ramírez, P.; Fernández-Fernández, D.; Lamas, J.A. Expression of K2P channels in sensory and motor neurons of the autonomic nervous system. J. Mol. Neurosci. 2012, 48, 86-96. [CrossRef]

50. Fernández-Fernández, D.; Cadaveira-Mosquera, A.; Rueda-Ruzafa, L.; Herrera-Pérez, S.; Veale, E.L.; Reboreda, A.; Mathie, A.; Lamas, J.A. Activation of TREK currents by riluzole in three subgroups of cultured mouse nodose ganglion neurons. PLoS ONE 2018, 13, e0199282. [CrossRef]

51. Medhurst, A.D.; Rennie, G.; Chapman, C.G.; Meadows, H.; Duckworth, M.D.; Kelsell, R.E.; Gloger, I.I.; Pangalos, M.N. Distribution analysis of human two pore domain potassium channels in tissues of the central nervous system and periphery. Brain Res. Mol. Brain Res. 2001, 86, 101-114. [CrossRef]

52. Talley, E.M.; Solorzano, G.; Lei, Q.; Kim, D.; Bayliss, D.A. CNS distribution of members of the two-pore-domain (KCNK) potassium channel family. J. Neurosci. 2001, 21, 7491-7505. [CrossRef]

53. Hervieu, G.J.; Cluderay, J.E.; Gray, C.W.; Green, P.J.; Ranson, J.L.; Randall, A.D.; Meadows, H.J. Distribution and expression of TREK-1, a two-pore-domain potassium channel, in the adult rat CNS. Neuroscience 2001, 103, 899-919. [CrossRef]

54. Gu, W.; Günter, S.; Jochen, R.H.; Hartmut, E.; Chiristine, K.S.; Andreas, K.S.; Christian, D.; Ortrud, K.S.; Jürgen, D. Expression pattern and functional characteristics of two novel splice variants of the two-pore-domain potassium channel TREK-2. J. Physiol.-London 2002, 539, 657-668. [CrossRef]

55. Yamamoto, Y.; Hatakeyama, T.; Taniguchi, K. Immunohistochemical colocalization of TREK-1, TREK-2 and TRAAK with TRP channels in the trigeminal ganglion cells. Neurosci. Lett. 2009, 454, 129-133. [CrossRef]

56. Talley, E.M.; Sirois, J.E.; Lei, Q.; Bayliss, D.A. Two-pore-Domain (KCNK) potassium channels: Dynamic roles in neuronal function. Neuroscientist 2003, 9, 46-56. [CrossRef]

57. Bang, H.; Kim, Y.; Kim, D. TREK-2, a new member of the mechanosensitive tandem-pore K+ channel family. J. Biol. Chem. 2000, 275, 17412-17419. [CrossRef]

58. Lesage, F.; Terrenoire, C.; Romey, G.; Lazdunski, M. Human TREK2, a 2P domain mechano-sensitive K+ channel with multiple regulations by polyunsaturated fatty acids, lysophospholipids, and Gs, Gi, and Gq protein-coupled receptors. J. Biol. Chem. 2000, 275, 28398-28405. [CrossRef]

59. Kim, J.S.; Park, J.Y.; Kang, H.W.; Lee, E.J.; Bang, H.; Lee, J.H. Zinc activates TREK-2 potassium channel activity. J. Pharmacol. Exp. Ther. 2005, 314, 618-625. [CrossRef]

60. Woo, J.; Shin, D.H.; Kim, H.J.; Yoo, H.Y.; Zhang, Y.H.; Nam, J.H.; Kim, W.K.; Kim, S.J. Inhibition of TREK-2 $\mathrm{K}(+)$ channels by PI $(4,5) \mathrm{P} 2$ : An intrinsic mode of regulation by intracellular ATP via phosphatidylinositol kinase. Pflugers Arch.-Eur. J. Physiol. 2016, 468, 1389-1402. [CrossRef] 
61. Kucheryavykh, L.Y.; Kucheryavykh, Y.V.; Inyushin, M.; Shuba, Y.M.; Sanabria, P.; Cubano, L.A.; Skatchkov, S.N.; Eaton, M.J. Ischemia increases TREK-2 channel expression in astrocytes: Relevance to glutamate clearance. Open Neurosci. J. 2009, 2, 40-47. [CrossRef]

62. Acosta, C.; Djouhri, L.; Watkins, R.; Berry, C.; Bromage, K.; Lawson, S.N. TREK2 expressed selectively in IB4-binding C-fiber nociceptors hyperpolarizes their membrane potentials and limits spontaneous pain. J. Neurosci. 2014, 34, 1494-1509. [CrossRef] [PubMed]

63. Pereira, V.; Busserolles, J.; Christin, M.; Devilliers, M.; Poupon, L.; Legha, W.; Alloui, A.; Aissouni, Y.; Bourinet, E.; Lesage, F.; et al. Role of the TREK2 potassium channel in cold and warm thermosensation and in pain perception. Pain 2014, 155, 2534-2544. [CrossRef]

64. Fink, M.; Lesage, F.; Duprat, F.; Heurteaux, C.; Reyes, R.; Fosset, M.; Lazdunski, M. A neuronal two P domain $\mathrm{K}+$ channel stimulated by arachidonic acid and polyunsaturated fatty acids. EMBO J. 1998, 17, 3297-3308. [CrossRef] [PubMed]

65. Lesage, F.; Maingret, F.; Lazdunski, M. Cloning and expression of human TRAAK, a polyunsaturated fatty acids-activated and mechano-sensitive $\mathrm{K}(+)$ channel. FEBS Lett. 2000, 471, 137-140. [CrossRef]

66. Meadows, H.J.; Chapman, C.G.; Duckworth, D.M.; Kelsell, R.E.; Murdock, P.R.; Nasir, S.; Rennie, G.; Randall, A.D. The neuroprotective agent sipatrigine (BW619C89) potently inhibits the human tandem pore-domain $\mathrm{K}(+)$ channels TREK-1 and TRAAK. Brain Res. 2001, 892, 94-101. [CrossRef]

67. Reyes, R.; Lauritzen, I.; Lesage, F.; Ettaiche, M.; Fosset, M.; Lazdunski, M. Immunolocalization of the arachidonic acid and mechanosensitive baseline traak potassium channel in the nervous system. Neuroscience 2000, 95, 893-901. [CrossRef]

68. Chemin, J.; Patel, A.J.; Duprat, F.; Lauritzen, I.; Lazdunski, M.; Honore, E. A phospholipid sensor controls mechanogating of the K+ channel TREK-1. EMBO J. 2005, 24, 44-53. [CrossRef]

69. Sandoz, G.; Bell, S.C.; Isacoff, E. Y Optical probing of a dynamic membrane interaction that regulates the TREK1 channel. Proc. Natl. Acad. Sci. USA 2011, 108, 2605-2610. [CrossRef]

70. Clapham, D.E. TRP channels as cellular sensors. Nature 2003, 426, 517-524. [CrossRef] [PubMed]

71. Voets, T.; Droogmans, G.; Wissenbach, U.; Janssens, A.; Flockerzi, V.; Nilius, B. The principle of temperature-dependent gating in cold- and heat-sensitive TRP channels. Nature 2004, 430, 748-754. [CrossRef]

72. Caterina, M.J.; Schumacher, M.A.; Tominaga, M.; Rosen, T.A.; Levine, J.D.; Julius, D. The capsaicin receptor: A heat-activated ion channel in the pain pathway. Nature 1997, 389, 816-824. [CrossRef]

73. Caterina, M.J.; Leffler, A.; Malmberg, A.B.; Martin, W.J.; Trafton, J.; Petersen-Zeitz, K.R.; Koltzenburg, M.; Basbaum, A.I.; Julius, D. Impaired nociception and pain sensation in mice lacking the capsaicin receptor. Science 2000, 288, 306-313. [CrossRef]

74. Woodbury, C.J.; Zwick, M.; Wang, S.; Lawson, J.J.; Caterina, M.J.; Koltzenburg, M.; Albers, K.M.; Koerber, H.R.; Davis, B.M. Nociceptors lacking TRPV1 and TRPV2 have normal heat responses. J. Neurosci. 2004, 24, 6410-6415. [CrossRef]

75. Bender, F.L.; Mederos, Y.S.M.; Li, Y.; Ji, A.; Weihe, E.; Gudermann, T.; Schafer, M.K. The temperature-sensitive ion channel TRPV2 is endogenously expressed and functional in the primary sensory cell line F-11. Cell Physiol. Biochem. 2005, 15, 183-194. [CrossRef]

76. Owsianik, G.; Talavera, K.; Voets, T.; Nilius, B. Permeation and selectivity of TRP channels. Annu. Rev. Physiol. 2006, 68, 685-717. [CrossRef]

77. Caterina, M.J.; Rosen, T.A.; Tominaga, M.; Brake, A.J.; Julius, D. A capsaicin-receptor homologue with a high threshold for noxious heat. Nature 1999, 398, 436-441. [CrossRef]

78. Nedungadi, T.P.; Dutta, M.; Bathina, C.S.; Caterina, M.J.; Cunningham, J.T. Expression and distribution of TRPV2 in rat brain. Exp. Neurol. 2012, 237, 223-237. [CrossRef]

79. Smith, G.D.; Gunthorpe, M.J.; Kelsell, R.E.; Hayes, P.D.; Reilly, P.; Facer, P.; Wright, J.E.; Jerman, J.C.; Walhin, J.P.; Ooi, L.; et al. TRPV3 is a temperature-sensitive vanilloid receptor-like protein. Nature 2002, 418, 186-190. [CrossRef]

80. Xu, H.; Ramsey, I.S.; Kotecha, S.A.; Moran, M.M.; Chong, J.A.; Lawson, D.; Ge, P.; Lilly, J.; Silos-Santiago, I.; Xie, Y.; et al. TRPV3 is a calcium-permeable temperature-sensitive cation channel. Nature 2002, 418, 181-186. [CrossRef] 
81. Peier, A.M.; Reeve, A.J.; Andersson, D.A.; Moqrich, A.; Earley, T.J.; Hergarden, A.C.; Story, G.M.; Colley, S.; Hogenesch, J.B.; McIntyre, P.; et al. A heat-sensitive TRP channel expressed in keratinocytes. Science 2002, 296, 2046-2049. [CrossRef]

82. Guler, A.D.; Lee, H.; Iida, T.; Shimizu, I.; Tominaga, M.; Caterina, M. Heat-evoked activation of the ion channel, TRPV4. J. Neurosci. 2002, 22, 6408-6414. [CrossRef]

83. Chung, M.K.; Lee, H.; Caterina, M.J. Warm temperatures activate TRPV4 in mouse 308 keratinocytes. J. Biol. Chem. 2003, 278, 32037-32046. [CrossRef]

84. Suzuki, M.; Mizuno, A.; Kodaira, K.; Imai, M. Impaired pressure sensation in mice lacking TRPV4. J. Biol. Chem. 2003, 278, 22664-22668. [CrossRef]

85. Todaka, H.; Taniguchi, J.; Satoh, J.; Mizuno, A.; Suzuki, M. Warm temperature-sensitive transient receptor potential vanilloid 4 (TRPV4) plays an essential role in thermal hyperalgesia. J. Biol. Chem. 2004, 279, 35133-35138. [CrossRef]

86. Watanabe, H.; Vriens, J.; Suh, S.H.; Benham, C.D.; Droogmans, G.; Nilius, B. Heat-evoked activation of TRPV4 channels in a HEK293 cell expression system and in native mouse aorta endothelial cells. J. Biol. Chem. 2002, 277, 47044-47051. [CrossRef] [PubMed]

87. Talavera, K.; Yasumatsu, K.; Voets, T.; Droogmans, G.; Shigemura, N.; Ninomiya, Y.; Margolskee, R.F.; Nilius, B. Heat activation of TRPM5 underlies thermal sensitivity of sweet taste. Nature 2005, 438, 1022-1025. [CrossRef]

88. Togashi, K.; Hara, Y.; Tominaga, T.; Higashi, T.; Konishi, Y.; Mori, Y.; Tominaga, M. TRPM2 activation by cyclic ADP-ribose at body temperature is involved in insulin secretion. EMBO J. 2006, 25, 1804-1815. [CrossRef] [PubMed]

89. Vriens, J.; Owsianik, G.; Hofmann, T.; Philipp, S.E.; Stab, J.; Chen, X.; Benoit, M.; Xue, F.; Janssens, A.; Kerselaers, S.; et al. TRPM3 is a nociceptor channel involved in the detection of noxious heat. Neuron 2011, 70, 482-494. [CrossRef] [PubMed]

90. Vandewauw, I.; De Clercq, K.; Mulier, M.; Held, K.; Pinto, S.; Van Ranst, N.; Segal, A.; Voet, T.; Vennekens, R.; Zimmermann, K.; et al. A TRP channel trio mediates acute noxious heat sensing. Nature 2018, 29, 662-666. [CrossRef] [PubMed]

91. Bandell, M.; Story, G.M.; Hwang, S.W.; Viswanath, V.; Eid, S.R.; Petrus, M.J.; Earley, T.J.; Patapoutian, A. Noxious cold ion channel TRPA1 is activated by pungent compounds and bradykinin. Neuron 2004, 41, 849-857. [CrossRef]

92. Peier, A.M.; Moqrich, A.; Hergarden, A.C.; Reeve, A.J.; Andersson, D.A.; Story, G.M.; Earley, T.J.; Dragoni, I.; McIntyre, P.; Bevan, S.; et al. A TRP channel that senses cold stimuli and menthol. Cell 2002, 108, 705-715. [CrossRef]

93. Thut, P.D.; Wrigley, D.; Gold, M.S. Cold transduction in rat trigeminal ganglia neurons in vitro. Neuroscience 2003, 119, 1071-1083. [CrossRef]

94. McKemy, D.D.; Neuhausser, W.M.; Julius, D. Identification of a cold receptor reveals a general role for TRP channels in thermosensation. Nature 2002, 416, 52-58. [CrossRef]

95. Fajardo, O.; Meseguer, V.; Belmonte, C.; Viana, F. TRPA1 channels mediate cold temperature sensing in mammalian vagal sensory neurons: Pharmacological and genetic evidence. J. Neurosci. 2008, 28, 7863-7875. [CrossRef] [PubMed]

96. Bautista, D.M.; Siemens, J.; Glazer, J.M.; Tsuruda, P.R.; Basbaum, A.I.; Stucky, C.L.; Jordt, S.E.; Julius, D. The menthol receptor TRPM8 is the principal detector of environmental cold. Nature 2007, 448, 204-208. [CrossRef] [PubMed]

97. Colburn, R.W.; Lubin, M.L.; Stone, D.J., Jr.; Wang, Y.; Lawrence, D.; D’Andrea, M.R.; Brandt, M.R.; Liu, Y.; Flores, C.M.; Qin, N. Attenuated cold sensitivity in TRPM8 null mice. Neuron 2007, 54, 379-386. [CrossRef]

98. Karashima, Y.; Talavera, K.; Everaerts, W.; Janssens, A.; Kwan, K.Y.; Vennekens, R.; Nilius, B.; Voets, T. TRPA1 acts as a cold sensor in vitro and in vivo. Proc. Natl. Acad. Sci. USA 2009, 106, 1273-1278. [CrossRef]

99. Jordt, S.E.; Bautista, D.M.; Chuang, H.H.; McKemy, D.D.; Zygmunt, P.M.; Hogestatt, E.D.; Meng, I.D.; Julius, D. Mustard oils and cannabinoids excite sensory nerve fibres through the TRP channel ANKTM1. Nature 2004, 427, 260-265. [CrossRef]

100. Story, G.M.; Peier, A.M.; Reeve, A.J.; Eid, S.R.; Mosbacher, J.; Hricik, T.R.; Earley, T.J.; Hergarden, A.C.; Andersson, D.A.; Hwang, S.W.; et al. ANKTM1, a TRP-like channel expressed in nociceptive neurons, is activated by cold temperatures. Cell 2003, 112, 819-829. [CrossRef] 
101. Bautista, D.M.; Jordt, S.E.; Nikai, T.; Tsuruda, P.R.; Read, A.J.; Poblete, J.; Yamoah, E.N.; Basbaum, A.I.; Julius, D. TRPA1 mediates the inflammatory actions of environmental irritants and proalgesic agents. Cell 2006, 124, 1269-1282. [CrossRef]

102. La, J.H.; Schwartz, E.S.; Gebhart, G.F. Differences in the expression of transient receptor potential channel V1, transient receptor potential channel A1 and mechanosensitive two pore-domain $\mathrm{K}+$ channels between the lumbar splanchnic and pelvic nerve innervations of mouse urinary bladder and colon. Neuroscience 2011, 186, 179-187. [PubMed]

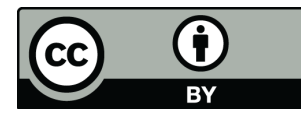

(C) 2019 by the authors. Licensee MDPI, Basel, Switzerland. This article is an open access article distributed under the terms and conditions of the Creative Commons Attribution (CC BY) license (http://creativecommons.org/licenses/by/4.0/). 